\title{
Pengembangan Multimedia Offline Terhadap Dampak Pandemi Virus Corona Covid 19 Pada Pelajaran Pkn Untuk Siswa Kelas VIII MTS NW Juet
}

\author{
${ }^{1}$ M. Ary Irawan, ${ }^{2}$ M. Samsul Hadi, ${ }^{3}$ Hadi Gunawan Sakti \\ Universitas Pendidikan Mandalika Mataram \\ Ary.irawan@gmail.com , samsul.hadi76@yahoo.co.id, gunawansakti33@gamil.com
}

\begin{abstract}
Abstrak. Penelitian ini bertujuan untuk menghasilkan Multimedia Pembelajaran PPKN Kelas VIII DI MTS JUET yang layak digunakan ditinjau dari segi isi, desain, dan media. Penelitian ini menggunakan metode Research and Development (R\&D). Subjek dalam penelitian ini adalah siswa kelas VIII di MTS JUET, Desa Lepak Timur Lombok Timur, Ujicoba multimedia dilakukan oleh ahli materi, ahli desain, dan ahli media. Hasil penelitian ini adalah sebagai berikut. hasil penilaian dari ahli isi terhadap multimedia interaktif diperoleh 95,80\%, dengan kualifikasi sangat baik, sehingga secara umum tidak perlu direvisi. Hasil penilaian dari seorang ahli desain pembelajaran sebesar $78 \%$ dengan kategori "Baik". Hasil penilaian dari ahli media sebesar 84,48\% dengan kategori "Baik". Hasil ujicoba kelompok kecil diperoleh 92,8\% dengan kategori "sangat baik". Ujicoba kelompok besar sebesar 94,49\% dengan kategori "sangatbaik". Hasil penilaian menunjukkan multimedia pembelajaran ini cocok digunakan dalam pembelajaran sehingga kayak untuk dipergunakan lebih lanjut lagi.
\end{abstract}

Kata kunci: Pengembangan Multimedia Offline, Dampak Pandemi, Virus Corona Covid 19, 


\section{PENDAHULUAN}

Teknologi pembelajaran sebagai studi praktek ilmiah pada pelaksanaannya bermuara pada aspek menciptkan (creating), dalam istilah yang lebih familiar dikenal sebagi kegiatan pengembangan. Kegiatan pengembangan dalam teknologi pembelajaran didefinisikan sebagai penerjemahan spesifikasi desain ke dalam bentuk fisik, dapat berupa teknologi cetak, teknologi audiovisual, teknologi berbasis komputer, dan teknologi terpadu (Seel \& Richey, 1994:35). Sehingga padat prakteknya di lapanga, kegiatan pengembangan dalam teknologi pemebelajaran bertujuan untuk menyediakan sumber atau bahan untuk belajar yang sesuai dengan kebutuhan pembelajaran.

Kebutuhan akan sumber/bahan untuk belajar saat ini menjadi perhatian yang utama pada setiap satuan pendidikan. Tiap satuan pendidikan dituntut untuk menyediakan fasilitasi belajar yang memadai. Tidak jarang ditemukan, bahwa kebutuhan akan sumber belajar yang sesuai dengan kebutuhan pebelajar mengharuskan pihak sekolah atau satuan pendidikan melakukan inovasi-inovasi baru dalam rangka menjawab tantangan pembelajaran yang terus berkembang, MA. MA NW JUET Kabupaten lombok Timur adalah salah satu dari sekian bayak lembaga swasta pendidikan yang tergolong masih memiliki kendala dalam pelaksanaan kegiatan-kegiatan belajar mengajarnya. Kendala tersebut terlihat sekali, Apa lagi maraknya Wabah Virus Korona sehingga proses pembelajaran terganggu,sehingga guru memliliki kreativitas dalam merancang pembelajaran yang berisifat online, akan tetapi dari pelaksanaan tersebut mengalami banyak hambatan yakni sinyal kurang karna letak geografis tempat tinggal siswa jauh dari jankauan sinyal belum stabil disebabkan di beberapa kota di sana sudah memiliki jaringan 4G, namun secara kecepatan masih seperti 3G.dan kemampuan untuk membeli kuota pulsa masih belum mampu bagi siswa yang memiliki ekonomi rendah.dan tidak semua siswa memiliki HP Android. Dalam Pelaksanaan kegiatan pembelajarannya kurang maksimal walaupun menggunakan pembelajaran secara online. penerapan pembelajaran daring terkendala banyak hal. Baik dari kompetensi gurunya, orang tua, maupun infrastruktur pendukung. Masih banyak orang tua yang tidak mempunyai keterampilan yang memadai atau Gaptek, akibatnya anak kesulitan dalam mengerjakan tugas dari gurunya

Permasalahan lainnya juga terutama pada pelaksanaan kegiatan pembelajaran di kelas $\mathrm{X}$ pada mata $\mathrm{PKn}$ adalah 6.5 nilai rata-rata tersebut belum mencapai KKM yakni 7.5 sesuai dengan hasil observasi dengan kepala sekolah dan guru bidang studinya. Kendala lainya juga yakni rendahnya hasil belajar pada mata pelajaran PKn pada kelas VIII terjadi dikarenakan penggunaan metode pengajaran yang kurang variatif sehingga selalu bersifat menoton, disamping itu pebelajar juga mengalami kesulitan memahami dan menghafal materi yang di ajarkan oleh gurunya dengan kondisi tersebut suasana proses pembelajaran kurang menyenangkan. Serta rendahnya hasil belajar pada mata pelajaran PKn pada kelas VIII disamping penyebabnya adalah metode guru yang tidak variatif dan siswa mengalami kesulitan dalam memahami dan menghafal materi pelajaran, terdapat juga kendala yang berpotensi menimbulkan persepsi tentang belajar menjadi kurang menarik, kendala tersebut adalah kaitanya dengan penggunaan media pembelajaran yang sesuai dengan materi dan dapat menarik perhatian pebelajar untuk belajar.Dengan mempertimbangkan berbagai persoalan yang dihadapi oleh guru dan pebelajar di kelas VIII MA. NW Juet, maka upaya pemecahan masalahnya dapat dilakukan dengan menciptkan atau mengembangkan media pembelajaran yang sesuai dengan karakteristik pebelajar dan kondisi situasi pada saat ini yakni wabah virus Corona (Covid 19), disamping itu juga harus sesuai dengan kebutuhan belajar pebelajar. Selain itu, media yang dikembangkan dalam hal ini harus di desain dalam bentuk tampilan menarik, dan yang paling penting pebelajar juga dapat bernavigasi dengan menggunakan 
media tersebut dalam belajarnya, Media pembelajaran yang memiliki karakteristik tersebut adalah multimedia Offline.

Multimedia merupakan suatu tampilan media yang dirancang oleh desainer agar tampilan memenuhi fungsi menginformasikan pesan dan memiliki interaktifitas kepada penggunanya. Dalam kegiatan pembelajarab multimedia interaktif merupakan salah satu media alternatif yang dapat digunakan untuk menunjang proses belajar mengajar, baik di dalam kelas maupun di luar kelas. Kepraktisan dan kemudahan penggunaan multimedia interaktif ini, diasumsikan dapat membantu pebelajar untuk belajar sesuai dengan harapkan, karena media ini mempunyai alur komunikasi dua arah. Pada penggunaanya, multimedia ini memiliki alur komunikasi dua arah, sehingga pebelajar melalui media ini dapat memperoleh informasi melalui pengolahan informasi belajar dalam bentuk verbal dan visual. Dalam proses belajar mengajar, multimedia interatif dapat dijadikan sebagai penunjang dalam model pembelajaran individual (Susilana, 2007:129 dan Smaldino,2005:148). Dalam pandangan spesifik, pembelajaran dengan menggunakan multimedia dapat menciptakan lingkungan pembelajaran berkualitas tinggi, dengan kemampuan menciptakan lebih banyak pembelajaran yang realistis dibandingkan dengan media lainnya (Sawsan, dkk 2005: 145), disamping itu, penggunaan multimedia dalam kegiatan pembelajaran bertujaun untuk mengembangkan tingkat interaktifitas sebagai bentuk dalam belajar, dan untuk memberikan peluang dalam rangka meningkatkan pengetahuan atau informasi pebelajar ( $\mathrm{Yu}$, Williams, Fu Lin, Chien Yu, 2008:218).

Mempertimbangkan hal-hal tersebut di atas, maka sangat perlu dilakukan pengembangan media pembelajaran dalam bentuk multimedia offline, sehingga dalam penelitian ini pengembang mengangkat judul: Pengembangan Multimedia Ofline Terhadap Dampak Pandemi Virus Corona Covid 19 Pada pelajaran PKn Untuk Siswa Ma Nw Juet.

\section{KAJIAN PUSTAKA \\ a. Multimedia}

Secara sederhana Mutimedia diartikan sebagai persentasi materi dengan menggunakan kata-kata dan gambar-gambar (Mayer, 2001:1). Secara lebih luas Multimedia diartikan sebagai pengintegrasian system komunkasi dalam sebuah perangkat khusus, seperti televisi, radio, komputer, notebook, netbook. (Darmawan,

2011:32). Akan tetapi seiring dengan perkembangan Teknologi Informasi dan Komunikasi, sekarang ini banyak penafsiran tentang Multimedia, diantaranya; Multimedia secara umum merupakan system komputer produk yang mengkombinasikan tiga elemen, yaitu suara, gambar dan teks, selain itu Multimedia juga di fahami sebagai alat yang dapat menciptakan presentasi yang dinamis dan Interaktif yang mengkombinasikan teks, animasi audio dan gambar video (McCormick, 1996 dan Robin dan Linda, 2001 dalam Dwiyogo, 2008, dan Roblyer dan Scwier dalam Mishra, 2005:3).

\section{b. Karakteristik Multimedia}

Dalam upaya mengembangkan Multimedia Interaktif, setidaknya produk Multimedia yang dihasilkan mampu meningkatkan motivasi dan hasil belajar bagi penggunanya, sehingga pengembang dala hal ini perlu memperhatikan karakteristik dari multimedia Interaktif (Susilana, 2007:126-129, diantaranya;

a. Self Instruction. Melaui produk Multimedia pembelajaran yang dihasilkan pebelajar dapat membelajarkan dirinya sendiri atau bisa juga dikatakan dengan produk Multimedia tersebut pebelajar dengan cara mandiri.

b. Self Contained. Seluruh materi pembelajaran dari satu kompetensi atau sub kompetensi yang dipelajari terdapat di dalam satu produk yang utuh. Tujuan dari konsep ini adalah memberikan kesempatan kepada pebelajar mempelajari materi pembelajaran secara tuntas, karena 
materi dikemas dalam satu kesatuan yang utuh.

c. Stand Alone. Produk Multimedia yang dikembangkan tidak bergantung pada bahan lain atau tidak harus digunakan bersama-sama dengan bahan ajar lain. Dengan menggunakan produk Multimedia yang dihasilkan pengembang, pebelajar tidak perlu menggunakan produk/bahan ajar yang lain untuk belajar dan mengajar tugastugas yang kaitannya dengan materi yang ada didalam produk.

d. Adaptif. Produk yang dihasilkan harus memiliki daya adaptif yang tinggi terhadap perkembnagan ilmu pengetahuan dan teknologi. Yakni sebisa mungkin produk Multimedia tersebut dapat menyesuaikan perkembangan ilmu pengetahuan dan teknologi, serta fleksibel digunakan di berbagai tempat.

e. User Friendly. Produk yang dihasilkan hendaknya bersahabat/akrab dengan pemakainya. Hal ini berkaitan dengan kemudahan pebelajar dalam merespon,

f. Representasi Isi. Dalam hal ini representasiisi berkaitan dengan tingkat inovasi yang dimunculkan oleh pengembang kaitannya dengan materi/konten yang akan dibelajarkan melalui Multimedia. Materi-materi dalam hal ini harus di seleksi yang betul-betul representasi untuk di buat dalam Multimedia Interaktif. Misalnya apabila terdapat materi yang membutuhkan unsur animasi atau video, pebelajar tidak hanya membaca teks tetapi juga menyerupai peruses yang sebenarnya.

g. Visualisasi dengan Multimedia (video, animasi, suara, teks dan gambar). Dalam hal ini materi yang dikemas dalam bentuk Multimedia Interaktif hendaknya terdapat teks, animasi, sound dan video sesuai tuntunan materi. Teknologi 2D dan 3D dengan kombinasi teks akan mendominasi kemasan materi, hal ini cukup efektif untuk mengajarkan materi-materi yang sifatnya aplikatif, berperoses, sulit terjangkau, berbahaya apabila langsung dipraktikkan, dan memiliki tingkat keakurasian tinggi. Sebagai contoh proses peraktikkan mesin, proses terjadinya hujan, peroses peredaran darah pada tubuh; dengan logika yang sama dapat dibuat dengan teknologi animasi.

h. Menggunakan Variasi yang Menarik dan Kualitas Resolusi yang Tinggi. Dalam hal ini tampilan berupa template dibuat dengan teknologi rekayasa digital dengan resolusi tinggi tetapi support untuk spec system komputer. Tampilan yang menarik dengan memperbanyak image dan objek sesuai tuntunan materi pelajaran, tidak sebaliknya yakni justru membuat pebelajar jenuh. Dalam hal ini perlu juga diperhatikan mengenai siapa yang akan belajar menggunakan produk Multimedia tersebut, sehingga unsurunsur yang dapat membuat Multimedia menjadi menarik (berkaitan dengan penggunaan warna dan animasi) dapat dituangkan/dimunculkan dalam produk Multimedia.

\section{Keunggulan dan Kelemahan Penggunaan Multimedia Interaktif Dalam Pembelajaran}

Diantara keunggulan penggunaan

Multimedia Interaktif dalam pembelajaran antara lain:

1. Learner Participation. Dapat meningkatkan partisipasi pebelajar dalam belajar.

2. Multiple Media. Dapat menggabungkan teks, audio, grafik, gambar dan animasi dala satu program yang dapat memudahkan penggunaan.

3. Individualization. Dapat meningkatkan kemandirian pebelajar di dalam belajar. 
4. Flexibility. Pembelajaran menjadi lebih menarik karena pebelajar bebas/fleksibel memilih materi yang akan dipelajari sesuai dengan menu belajar yang ada dalam Multimedia interaktif.

5. Simulations. Penggunaan Multimedia Interaktif lebih di asumsikan dapat mengifensienkan kegiatan pembelajaran melalui penyediaan informasi belajar yang lebih sederhana dan akurat. Seperti simulasi tentang operasi mesin yang rumit, dengan Multimedia Interaktif cara kerja operasi mesin tersebut bisa dihadirkan di dalam kelas.

6. Dapat menumbuhkan kreatifitas pebelajar dalam belajar. Hal tersebut terlihat dari rancangan isi dan desain Multimedai yang di dalamnya memberi peluang dalam pebelajar dalam menumbuh kembangkan kreatifitas belajar melalui adaa tampilan materi yang menarik dan disertai latihan-latihan.

7. Dapat meningkatkan motivasi belajar pebelajar. Yakni melalui tampilan multimedia interaktif yang mengkombinasikan teks, gambar, grafik, animasi, audio dan video secara serasi.

\section{METODE PENELITIAN Model Pengembangan}

Dalam penelitian dan pengembangan ini, model yang menjadi acuan adalah model procedural penelitian pengembangan yang dikembangkan oleh Brog \&Gall,1983:775776), yang meliputi langkah-langkah berikut; (1) Reseach and information collecting, (2) Planning, (3) Develop Preliminary form of product, (4) Preliminary filed testing, (5) Main product revision, (6) Main filed testing, (7) Operational product revision, (8) Operational filed testing, (9) Final product revision,

Adapun yang menjadi subjek coba dălam penelitian ini adalah; ahli isi atau materi, ahli media pembelajaran, ahli desain, guru bidang studi dan pebelajar Kelas VIII MA.NW Juet. Berdasarkan model pengembangan yang dikembangkan oleh Brog \& Gall, terdapat sepuluh langkah procedural yang harus dilakukan oleh pengembang. Akan tetapi dalam kegiatan penelitian ini pengembang hanya menggunakan 8 (delapan) langkah saja. Adapun yang menjadi subjek coba dalam penelitian ini adalah; ahli isi atau materi, ahli media pembelajaran, ahli desain, guru bidang studi dan pebelajar Kelas VIII MTS JUET. Berdasarkan data yang akan digunakan, data dibagi kedalam dua jenis, yaitu data kualitatif dan data kuantitatif. Data kualitatif didapatkan dari hasil wawancara dan hasil sasaran ahli isi, ahli desain, dan ahli media, baik pada tahap uji validasi atas uji lapangan. Sedangkan kuantitatif diperoleh dari hasil angket, yang disebarkan kepada subjek coba. Untuk memperoleh sejumlah data yang diharapkan, dalam penelitian ini digunakan instrument pengumpulan data yaitu wawancara dan angket. Sedangkan Analisis data dalam penelitian dan pengembangan ini dibagi dalam dua jenis, yaitu analisis deskriptif kualitatif dan analisis statistic deskriptif.Setelah didapatkan hasil dari data yang diolah dengan menggunakan rumus diatas, hasil tersebut dicocokan dengan kriteria kelayakan, dapat dilihat pada tabel 3.1 sebagai berikut:

\begin{tabular}{|l|ll|l|l|}
\hline Kategori & Presentase & Kualifikasi & Ekuivalen \\
\hline A & 76 & -100 & Valid & Sangat \\
B & 51 & -75 & Cukup valid & Laya \\
C & 35 & -50 & Kurang valid & Cukup \\
D & $0 \%-34 \%$ & Kurang Valid & $\begin{array}{l}\text { Kurang } \\
\text { Layak }\end{array}$ \\
\hline
\end{tabular}

Keterangan pada tabel 3.1 kriteria tingkat kelayakan yakni:

a) Apabila media yang diuji cobakan tersebut mencapai tingkat presentase $75 \%-100 \%$, maka media tersebut tergolong kualifika Sangat valid/ layak.

b) Apabila media yang diuji cobakan tersebut mencapai tingkat presentase $51 \%-75 \%$,maka media tersebut tergolong kualifikasi valid/layak.

\section{HASIL DAN PEMBAHASAN Uji ahli Isi Mata Pelajaran}

Produk pengembangan ini berupa multimedia offline pada mata pelajaran PPKN. Adapun 
ahli isi materi mata pelajaran PPKN yaitu Ibu Chandra Rahayu,S.Pd. Beliau adalah guru senior pada mata pelajaran PPKN Yang mana beliau juga sebagai tutor untuk guru-guru PPKN di semua sekolah swasta di MA dan beliau juga sering mengikuti pelatihanpelatihan tentang aplikasi komputer. Produk pengembangan ini diserahkan kepada ahli isi pada tanggal 17 Mei 2020 .Data yang diperoleh dari ahli isi mata pelajaran berupa data kualitatif dalam bentuk angket komentar dan saran pada bahan ajar multimedia offline. Hasil penilaian ahli isi terhadap bahan ajar multimedia interaktif dapat dilihat dalam tabel 4.1 sebagai berikut:

Tabel 4.1 Data Hasil Penilaian Ahli Isi Materi Terhadap Bahan ajar Multimedia Offline

\begin{tabular}{cccc}
\hline Jumlah item pertanyaan & Skor & Frekuensi & Persentase \\
\hline 20 & 5 & 15 & $78,94 \%$ \\
\cline { 2 - 4 } & 4 & 5 & $16,84 \%$ \\
\hline Jumlah & & & $\mathbf{9 5 , 8 0 \%}$ \\
\hline
\end{tabular}

Masukan saran dan komentar ahli isi mata pelajaran yang berkenan dengan bahan ajar multimedia offline adalah sebagai berikut :

1) Kekontrasan warna

2) Konsistensi keterangan nama gambar Berdasarkan hasil penilaian dari seorang ahli isi terhadap bahan ajar multimedia offline sebagaimana tercantum pada tabel 4.1 di atas, hasil perhitungan persentase diperoleh $95,80 \%$. Setelah dikonversikan dengan tabel konversi menunjukkan bahwa bahan ajar multimedia offline berada dalam kualifikasi sangat baik, sehingga secara umum tidak perlu direvisi.

Berdasarkan penilaian dari ahli isi mata pelajaran, maka tidak dilakukan revisi. Semua persentase pencapaian kelayakan, baik pada bahan ajar multimedia offline dalam kategori sangat baik, sehingga tidak perlu direvisi. Namun pengembang tetap melakukan perbaikan sesuai saran ahli isi mata pelajaran.

\section{Uji Ahli Media Pembelajaran}

Produk pengembangan paket pembelajaran ini juga diberikan kepada seorang ahli media pembelajaran. Bahan ajar multimedia offline dan instrument berupa agket diserahkan pada tanggal 20 Juni 2020 Ahli media pembelajaran yang diminta untuk menilai produk pengembangan adalah bapak Ary Purmadi, S.Pd, Beliau adalah seorang Teknologi pendidikan dan juga dosen sekaligus menjadi Kepala Lab. Jurusan di Program Studi Teknologi Pendidikan (S1) di UNDIKMA. Adapun instrument yang digunakan adalah angket. Berkaitan dengan desain pembelajaran, produk pengembangan yang diminta untuk dinilai oleh ahli media pembelajaran adalah bahan ajar multimedia offline.

Hasil penilaian ahli media pembelajaran terhadap bahan ajar multimedia offline adalah sebagai berikut :

Tabel 4.2 Hasil Penilaian Ahli Media Pembelajaran Terhadap Bahan Ajar multimedia Ineteraktif

\begin{tabular}{|c|c|c|c|}
\hline $\begin{array}{c}\text { Jumlah item } \\
\text { pertanyaan }\end{array}$ & Skor & Frekuensi & Persentase \\
\hline 10 & 5 & 3 & $22,23 \%$ \\
\hline & 4 & 7 & $62,25 \%$ \\
\hline Jumlah & & & $\mathbf{8 4 , 4 8 \%}$ \\
\hline
\end{tabular}

Masukan, saran dan komentar ahli media pembelajaran berkenaan dengan bahan ajar multimedia offline ini ini dapat memadai untuk dilakukan uji berikutnya.

1.Kualitas gambar didalam panduan guru perlu dipertajam

2. Kekonsistenan ukuran gambar

Berdasarkan hasil penilaian dari seorang ahli media pembelajaran terhadap bahan ajar multimedia interaktif tercantum pada tabel 4.8 di atas, hasil perhitungan persentase diperoleh sebesar $84,48 \%$. Setelah dikonversikan dengan tabel konversi menunjukkan bahwa panduan guru berada dalam kualifikasi baik sehingga tidak perlu direvisi.

Produk pengembangan ini masih perlu dilakukan perbaikan-perbaikan pada beberapa bagian dalam produk pengembangan berdasarkan masukan dan saran dari ahli media pembelajaran.

Berdasarkan penilaian dari ahli media,maka tidak dilakukan revisi. Semua persentase pencapaian kelayakan, baik pada bahan ajar multimedia interaktif dalam ketegori sangat baik, sehingga tidak perlu direvisi. Namun tetap melakukan perbaikan sesuai saran ahli media.

Uji Ahli Desain Pembelajaran 
Produk pengembangan multimedia offline ini juga diberikan kepada seorang ahli desain pembelajaran. Bahan ajar multimedia interaktif dan instrument berupa angket diserahkan kepada ahli desain pembelajaran tanggal 6 September 2011. Ahli desain pembelajaran yang diminta untuk menilai produk pengembangan adalah Moh. Husen Basya M.Pd,. Beliau mengambil prodi Teknologi pembelajaran, dosen di UNDIKMA. Adapun instrument yang digunakan adalah angket. Berkaitan dengan desain pembelajaran, produk pengembangan yang diminta untuk dinilai adalah bahan ajar multimedia offline.

Dibawah ini disajikan hasil penilaian ahli desain pembelajaran terhadap produk pengembanga berupa panduan siswa.

Tabel 4.3 Hasil Penilaian Ahli Desain Pembelajaran Terhadap Produk Pengembanganr Multimedia offline

\begin{tabular}{c|c|c|c|}
\hline Jumlah item pertanyaan & Skor & Frekuensi & Persentase \\
\hline 10 & 5 & 3 & $33 \%$ \\
\hline & 4 & 5 & $32 \%$ \\
\hline & 3 & - & \\
\hline & 2 & 2 & $13 \%$ \\
\hline Jumlah & & & $\mathbf{7 8 \%}$ \\
\hline
\end{tabular}

Masukan, saran dan komentar ahli desian pembelajaran berkenaan dengan panduan siswa adalah sebagai berikut:

1. Dipertimbangkan desain cover harus disesuaikan dengan isi materi

2. Usahakan agar konsistenan dalam penulisan, pewarnaan dan desain bahan multimedia

Berdasarkan hasil penilaian dari seorang ahli desain pembelajarann terhadap panduan siswa sebagaiamana tercantum pada tabel 4.3 di atas, hasil perhitungan persentase diperoleh sebesar $78 \%$. Setelah dikonversikan dengan tabel konversi menunjukkan bahwa bahan ajar multimedia offline siswa berada dalam kualifikasi baik sehingga tidak perlu direvisi.Produk pengembangan ini masih perlu dilakukan perbaikan-perbaikan pada beberapa bagian dalam produk pengembangan berdasarkan masukan dan saran-saran dari ahli desain pembelajaran.

Uji Kelompok Kecil 1.Bahan Ajar Multimedia Offline
Berikut ini disajikan data yang diperoleh dari uji coba kelompok kecil sajian data dimulai dari bahan ajar multimedia offline .

Tabel 4.4 Data Hasil Uji Coba Kelompok Kecil Terhadap Multimedia Offline

\begin{tabular}{|c|c|c|c|c|c|c|c|c|}
\hline \multirow[b]{2}{*}{$\begin{array}{c}\text { Item } \\
\text { Pertanyaan }\end{array}$} & \multicolumn{8}{|c|}{ Frekuensi Dengan Skala 5} \\
\hline & 1 & 2 & 3 & 4 & 5 & Jmlh & $\%$ & $\begin{array}{c}\text { Komentar/ } \\
\text { Saran }\end{array}$ \\
\hline 1 & - & - & - & 2 & 10 & 12 & 96,67 & \\
\hline 2 & - & - & - & 3 & 9 & 12 & 95 & Tidak ada \\
\hline 3 & - & - & - & 6 & 6 & 12 & 93 & Tidak ada \\
\hline 4 & - & - & - & 6 & 6 & 12 & 90,00 & Tidak ada \\
\hline 5 & - & - & - & 6 & 6 & 12 & 90,00 & Tidak ada \\
\hline 6 & - & - & - & 3 & 9 & 12 & 95 & Tidak ada \\
\hline 7 & - & - & - & 1 & 11 & 12 & 98,33 & Tidak ada \\
\hline 8 & - & - & - & 7 & 5 & 12 & 88,33 & Tidak ada \\
\hline 9 & - & - & - & 8 & 4 & 12 & 86,67 & Tidak ada \\
\hline 10 & - & - & - & 3 & 9 & 12 & 95 & Tidak ada \\
\hline Jumlah & & & & & & & 928,00 & \\
\hline Rata-rata & & & & & & & 92,8 & \\
\hline
\end{tabular}

Berdasarkan penilaian/ tanggapan sebagaimana tercantum dalam tabel 4.4 diketahui bahwa rata-rata persentase tingkat pencapaian bahan ajar $92,8 \%$, rerata tersebut bila dikonversikan dengan tabel kelayakan, maka bahan ajar multimedia offline berada dalam kualifikasi sangat baik dan tidak perlu direvisi.

Rangkuman masukan, saran, dan komentar 12 orang siswa dalam uji coba kelompok kecil yang berkenaan dengan Bahan ajar Multimedia Offline adalah sebagai berikut :

Tabel 4.36 Revisi Masukan, Saran Dan omentar Uji Coba Kelompok Kecil Pada Bahan Ajar Multimedia Offline

\begin{tabular}{|l|l|l}
\hline No & Masukan,Saran, dan Komentar & \multicolumn{1}{|c}{ Revisi } \\
\hline 1 & Bahan jar mudah dipahami & Tidak ada revisi \\
\hline 2. & Sebaiknya cover lebih cerah & Penambahan kecerahan warna pada samp \\
\hline 3 & Gambarnya yang menarik & Tidak ada revisi \\
\hline
\end{tabular}

\section{Uji Coba Lapangan}

Data-data yang diperoleh dari kegiatan uji coba lapangan disajikan secara berurutan mulai dari bahan ajar multimedia offline dan tanggapan guru.

\section{a. Multimedia Offline}

Hasil penilaian uji coba lapangan terhadap

Bahan ajar dapat dilihat pada tabel 4.5 sebagai berikut :

Tabel 4.5 Data Hasil Uji Coba Lapangan Terhadap multimedia offline 


\begin{tabular}{|c|c|c|c|c|c|c|c|c|}
\hline \multirow{2}{*}{$\begin{array}{c}\text { Item } \\
\text { Pertanyaan }\end{array}$} & \multicolumn{5}{|c|}{ Frekuensi Dengan Skala 5} & \multirow[t]{2}{*}{ Jmlh } & \multirow[t]{2}{*}{$\%$} & \multirow{2}{*}{$\begin{array}{l}\text { Komenta } \\
\text { r/ Saran }\end{array}$} \\
\hline & 1 & 2 & 3 & 4 & 5 & & & \\
\hline 1 & - & - & - & 6 & 24 & 30 & 96 & Tidak ada \\
\hline 2 & - & - & - & 11 & 19 & 30 & 92,66 & \\
\hline 3 & - & - & 2 & 11 & 17 & 30 & 90 & \\
\hline 4 & - & - & - & 7 & 23 & 30 & 95,33 & \\
\hline 5 & - & - & - & 7 & 23 & 30 & 95,34 & \\
\hline 6 & - & - & - & 13 & 17 & 30 & 91,34 & \\
\hline 7 & - & - & 1 & 6 & 23 & 30 & 94,67 & \\
\hline 8 & - & - & - & 9 & 21 & 30 & 94 & \\
\hline 9 & - & - & - & 10 & 20 & 30 & 93,33 & \\
\hline 10 & - & - & 1 & 10 & 19 & 30 & 89,34 & \\
\hline JUMLAH & & & & & & & 944,95 & \\
\hline Rata-rata & & & & & & & 94,495 & \\
\hline
\end{tabular}

Berdasarkan data hasil angket tanggapan guru terhadap bahan ajar dalam uji coba lapangan sebagaimana tercantum pada tabel 4.5 di atas, skor yang diperoleh terhadap 30 komponen bahan ajar multimedia offline adalah skor 5 ( sangat baik), skor 4 ( Baik). Rerata persentase diperoleh sebesar 93,49 \% Setelah dikonversikan dengan tabel konversi diketahui bahwa bahan ajar multimedia offline berada dalam kualifikasi sangat baik.

Rangkuman masukan, saran, dan komentar dari siswa berkenaan dengan bahan ajar multimedia adalah sebagai berikut :

Tabel 4.6 Revisi masukan, Saran Dan Komentar Terhadap Bahan ajar

\begin{tabular}{|l|l|l|}
\hline $\mathrm{N}_{0}$ & \multicolumn{1}{|c|}{ Masukan,saran dan komentar } & \multicolumn{1}{|c|}{ Revisi } \\
\hline 1 & Bahan ajar mudah dipahami & Tidak direvisi \\
\hline 2 & $\begin{array}{l}\text { Ukuran tulisanya besar dan hurufnya } \\
\text { mudah dibaca }\end{array}$ & Tidak direvisi \\
\hline
\end{tabular}

\section{KESIMPULAN}

Pengembangan bahan ajar multimedia offline mata pelajaran PPKN kelas VIII ini menggunakan model pengembangan borg dan gall yang proses pengembangannya hanya sampai pada tahap kesembilan tahap pengembangan. Hasil analisis data menyimpulkan bahwa dari beberapa uji ahli isi, media dan disain dan uji coba kelompok kecil dan kelompok besar bahwa pengembangan multimedia offline dapat kualifikasi Baik (Layak).

\section{SARAN}

Multimedia offline ini dapat dikembangkan untuk kelas dan semester yang laian dalam tingkat satuan pendidikan yang sama. Sedangkan untuk kelas dan semester yang sama paket ini perlu dilengkapi dengan program pengayaan dan remidiasi sebagaimana diamanatkan dalam standar proses KTSP.

Pengembangan produk ini disempurnakan, mengingat model yang digunakan adalah Borg dan Gall. Dalam setiap tahapan yang melakukan evaluasi perlu disesuaikan antara evaluasi yang dilakukan dengan penyajian materi. Multimedia akan lebih baik jika disertai dengan media cetak berupa buku ajar, buku panduan guru dan siswa.

\section{DAFTAR PUSTAKA}

AlanJanuszewski \& Michael Molenda, 2008. Educational Technology " $A$

Definition with Commentary". Washington DC: AECT.

Ariani. Niken \& Dany Hariyanto, 2010. Pembelajaran Multimedia di

Sekolah : Pedoman Pembelajaran Inspiratif, Konstruktif, dan Prospektif. Jakarta: Prestasi Pustaka.

Borg W,R. and Gall M. D., Educational Research : An Aintroduction, 4 th

edition, London: Longman Inc., 2003.

BSNP, 2006. Badan Standar Nasional Pendidikan. Jakarta : Depdiknas.

Darmawan, Deni. 2011. Teknologi Pembelajaran Bandung: PT. Remaja

Rosdakarya.

Dwiyogo, Waisis. 2008. Aplikasi Teknologi Pembelajaran: Media

Pembelajaran Penjas dan Olahraga. FIP: Universitas Negeri

Malang.

Hoftsteter, Fredt. 2001. Multimedia Literacy. New York: Mc. Grow-Hill Companies.

Komalasari, K \& syaifullah. (2009). Kewarganegaraan Indonesia konsep perkembangan dan masalah kontemporer. Bandung: Lab PKn UPI Mayer, E Richard. 2009. Multimedia Learning: Prinsip-Prinsip dan

Aplikasi. Yogyakarta: Pustaka Pelajar.

Sanjaya, Wina. 2011. Strategi Pembelajaran Berorientasi Standar Proses 
Pendidikan. Jakarta: Kencana

Prenada Media.

Mishra, Sanjaya. 2005. Interactive in Education and Training. Idea Grop

Inc,

Rob PhilIPA. 1997. The developer's Handbooks to Interactive Multimedia:

A Paractive Guide for Educational Applications. London: Kogan

Page Limited.

Seels, B.B. \& Richey, R.C. 1994. Intructional Technology: The Definition and Domain of the Field. Washington DC: AECT.

Seels, B.B. \& Richey, R.C. 1994. Ekologi Pembelajaran: Definisi dan

Kawasannya (terjemahan). Washington DC: AECT.

Smaldino, Sharon E. 2005. Instuctional Technology and Multimedia For Learning. Eighth Edition. Columbus, Person Education. 